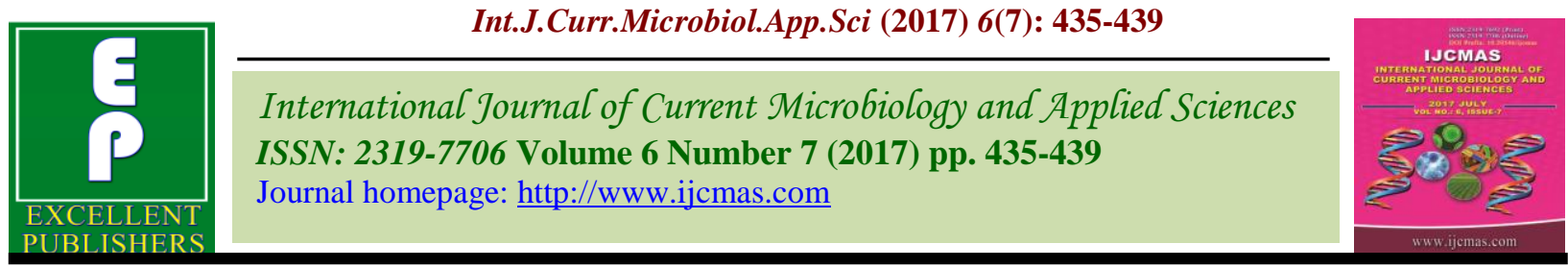

Original Research Article

https://doi.org/10.20546/ijcmas.2017.607.052

\title{
Eco-Friendly Management of Powdery Mildew of Green Gram (Vigna radiata L.)
}

\author{
Rajesh Kumar Yadav ${ }^{*}$, S.S. Kakraliya ${ }^{2}$, M.R. Bajiya ${ }^{3}$ and Sonali Abrol ${ }^{2}$ \\ ${ }^{1}$ Department of Plant Pathology, Sam Higginbottom Institute of Agriculture, Technology and \\ Sciences (Deemed-to-be-University), Allahabad-211007, Uttar Pradesh, India \\ ${ }^{2}$ Division of Plant Pathology, ${ }^{3}$ Division of Entomology, SKUAST-Jammu, India \\ *Corresponding author
}

\section{A B S T R A C T}

\begin{tabular}{l} 
Ke y w o r d s \\
Carbendazim, \\
Erysiphe polygoni, \\
Pseudomonas \\
fluorescens, \\
Trichoderma \\
viride, \\
Trichoderma \\
harzianum, Plant \\
extracts. \\
\hline Article Info \\
\hline $\begin{array}{l}\text { Accepted: } \\
\text { 04 June } 2017 \\
\text { Available Online: } \\
10 \text { July } 2017\end{array}$ \\
\hline
\end{tabular}

The present study was conducted during consecutive Kharif season of 2014-2015. An experiment was conducted to evaluate the efficacy of selected fungicide, bio-agents, botanicals against powdery mildew (Erysiphe polygoni). To manage the disease on investigation was carried out in the Department of Plant Pathology, SHIATS- DU, Allahabad to evaluate the efficacy of bio-agents viz., Pseudomonas fluorescens @ 2\%, Trichoderma viride@2.5\%,Trichoderma harzianum @ 2.5\%, plant extracts viz., neem leaf extract@10\%,garlic clove extract @10\% and fungicide viz., Carbendazim @ 0.1\% against powdery mildew (Erysiphe polygoni). In-situ (field) experiment was carried out in randomized block design with seven treatments and three replications. T. viride@2.5\% was found to be most effective treatment and recorded minimum disease intensity (15.98\%) followed by Pseudomonas fluorescens @ 2\% (18.04\%), T. harzianum @ 2.5\% (20.26\%), neem leaf extract @ 10\% (21.55\%), garlic clove extract @ 10\% $(22.87 \%)$ and fungicide viz., Carbendazim @0.1\% (14.27\%). Use of T. viride@ $2.5 \%(65.99 \mathrm{~cm})$ recorded maximum plant height $(42.62 \mathrm{~cm}$ and $65.99 \mathrm{~cm}$ at 45 and 75 DAS, respectively). Maximum number of pods was recorded in $T$. viride (13.30 and 14.27, respectively) followed by $P$. fluorescens $(13.00 \% 14.07 \%$, respectively) as compared to control which reordered minimum number of pods per plant (8.50 and 9.60 , respectively). The highest seed weight (g/plot) was recorded in T.viride (37.95 g) followed by P. fluorescens $(37.47$ $\mathrm{g}$ ) as compared to $\left.\mathrm{T}_{0}\right)$.

\section{Introduction}

Mungbean (Vigna radiate L.), belongs to the family leguminosae and sub family Papilionaceae. Pulses are major sources of proteins among the vegetarians in India, and complement the staple cereals in the diets with proteins, essential amino acids, vitamins and minerals. They contain $22-24 \%$ protein, which is almost twice the protein in wheat and thrice that of rice. Pulses provide significant nutritional and health benefits, and are known to reduce several noncommunicable diseases such as colon cancer and cardio- vascular diseases. Production followed by pigeon pea (18-20\%), mungbean (11\%), urdbean $(10-12 \%)$, lentil $(8-9 \%)$ and other legumes (20\%) (Laxmipathi et al., 2013). Green gram is grown mainly as a kharif season crop. However, its cultivation in Rabi season is restricted to the eastern and southern parts of the country. The major 
green gram growing states are Orissa, Madhya Pradesh, Maharashtra, Uttar Pradesh, Andhra Pradesh, Rajasthan, Punjab, Karnataka and Gujarat. It ranks third among all pulses grown in India after chickpea and pigeon pea. Orissa stands first in area, production as well as productivity of green gram in India. It is followed by Maharashtra, and Madhya Pradesh in area and production. The crop is generally grown during Kharif as rainfed crop. Among the diseases, powdery mildew caused by Erysiphe polygoni is one of the economically important diseases in green gram which occur at later stages of crop growth. Grain yield losses have been reported up to $21 \%$ due to powdery mildew in green gram (Quebral and Cowel 1978). Losses are much high when the pathogen infects the crop before flowering, however, it results in complete loss of the crop if disease occurs at seedling stage. Abbaiah (1993) reported that the powdery mildew in Urdbean was generally noticed in 45 days old crop. Similarly, Venkata Rao (1997) observed that 40 and 50 days old green gram plants were highly susceptible to powdery mildew

The disease first appears on the leaves; in its advanced stage, stems and pods become infected, resulting in yield loss. The disease reduced yield of green gram between 21 and 40 per cent (Soria and Quebral, 1973) in the Philippines and up to 40 per cent in Taiwan (AVRDC, 1984). Powdery mildew occurs under cool temperatures $\left(22{ }^{\circ} \mathrm{C}\right.$ to $\left.30{ }^{\circ} \mathrm{C}\right)$ and is favoured by cloudy weather. Powdery mildew is easily recognized white, powdery growth of the fungus on infected portions of the plant host. The powdery appearance results from the superficial growth of the fungus as a thread-like stands (hyphae) over the plant surface and the production of chains of spores (conidia). In the early stages of infection, light yellowish, irregular spots appear on the leaves, which rapidly turn brown. A powdery mass grows over the spots covering the entire leaf surface. The fungus is an obligate parasite that requires living hosts to complete their life cycle.

\section{Materials and Methods}

\section{In-situ experiment}

In situ experiment (field) was laid out in randomized block design (RBD) with seven treatments Viz. Carbendazim @0.1\%, Pseudomonas fluorescens @2\%, Neem leaf extract@10\%, Garlic clove extract@10\%, Trichoderma viride@2.5\% Trichoderma harzianum @2.5\% and three replications including inoculated check in the experimental field of SHIATS, Allahabad in kharif season (2014-2015). Each replication consisted of 21 plots of $2 \times 1 \mathrm{~m} 2$ each. The seeds cv. "T- 44" was sown in February with a spacing of $10 \times 45 \mathrm{~cm}$. Bioagent and botanicals were sprayed just after initiation of disease and repeated three at 15 days interval. Plots without sprays server as check the observations were recorded in five selected tagged plants 3 days after last sprays of botanicals using 0 to 9 grade scale (Kapadiya and Dhruj, 1999) (Table 1). The data was subjected to the statistical analysis.

\section{Preparation of fungicidal spray solution}

The spray solution of a desired concentration was prepared by adopting the following formula.-

$\mathrm{V}=\frac{\mathrm{C} \times \mathrm{A}}{------}$

Where,

$\mathrm{V}=$ Volume/weight of commercial fungicide $\mathrm{ml}$ or $\mathrm{g}$

$\mathrm{C}=$ Concentration required

$\mathrm{A}=$ Volume of solution to be prepared 
$\%$ a.i. = percentage of active ingredient in commercial product

Disease intensity (\%) was calculated by using the following formula

Sum of all disease ratings Disease intensity $(\%)$

Disease intensity $(\%)=$ x 100

Total number of leaves/plant $\mathrm{x}$ Maximum disease grade

\section{Results and Discussion}

The result presented in table 2 revealed that all the treatments were statistically significant and increased plant height as compared to control. Among the bio agents and botanicals the maximum plant height $(\mathrm{cm})$ was recorded in $\mathrm{T}_{5}$ - Trichodermaviride @ 2.5\% (65.99 $\mathrm{cm})$ followed by $\mathrm{T}_{2}$ - Pseudomonas fluorescens @ 2\% $(65.10 \mathrm{~cm}), \mathrm{T}_{6}$ Trichoderma harzianum @ 2.5\% (64.15cm), $\mathrm{T}_{1-}$ Carbendazim@0.1\% (63.13), T $\mathrm{T}_{3}$-Neem leaf extract@10\%(62.11 cm), T $4^{-}$Garlic extract@10\% (61.88cm), as compared to $\mathrm{T}_{0}$ control $(59.53 \mathrm{~cm})$.Among the treatments maximum plant height $(\mathrm{cm})$ in $\mathrm{T}_{5}-$ Trichoderma viride $(65.99 \mathrm{~cm})$. The bio agents and botanicals the minimum number of pod per plant was recorded in $\mathrm{T}_{5}$ Trichoderma viride @ 2.5\% (7.44\%) as compared to treated and untreated control (7.76\% and $5.57 \%$ and respectively). $\mathrm{T}_{5}-$ Trichoderma viride treatment was followed by $\mathrm{T}_{2^{-}}$Pseudomonas fluorescens @2.5\% (7.10\%), $\mathrm{T}_{3^{-}}$Neem leaf extract @ 20\% (7.07\%), $\mathrm{T}_{6}$ - Trichoderma harzianum@2.5\% $(6.87 \%)$ and $\mathrm{T}_{4}$ - Garlic extract @ 10\% (5.95\%) as compared to T0 - control (5.95\%). Among the treatments No of pod per plant of mung bean was recorded in $\mathrm{T}_{1}$ - Carbendazim 50 WP @ $0.1 \% \quad(7.76 \%)$ and $\mathrm{T}_{5}$ Trichodermaviride@2.5\% (7.44\%).

The results presented in table 2 revealed that all the treatments were statistically significant and decreased disease intensity as compared to control. Among the bio-agents and botanicals used the maximum plant height was recorded in T5 Trichoderma viride (65.99 $\mathrm{cm})$ as compared to treated and untreated controls (63.13and $59.53 \mathrm{~cm}$ respectively) (Plate 1). minimum disease intensity percent was recorded in T2- Pseudomonas fluorescens@2\%(18.04\%) as compared to treated and untreated control $(20.15 \%$ and $14.27 \%$ and respectively).

Table.1 Different treatments

\begin{tabular}{ll}
\hline Treatments & Treatment name \\
\hline $\mathrm{T}_{0}$ & Untreated Control \\
$\mathrm{T}_{1}$ & Carbendazim @ 0.1\% (treated control) (FS) \\
$\mathrm{T}_{2}$ & Pseudomonas fluorescens @2\% (FS) \\
$\mathrm{T}_{3}$ & Neem leaf extract @ 10\% (FS) \\
$\mathrm{T}_{4}$ & Garlic clove extract @ 10\%, (FS) \\
$\mathrm{T}_{5}$ & Trichoderma viride @ 2.5\% (FS) \\
$\mathrm{T}_{6}$ & Trichoderma harzianum @2.5\% \\
\hline
\end{tabular}

$\mathrm{FS}=$ foliar spray 
Table.2 Per cent disease intensity of Erysiphe polygoni and plant growth of green gram at 60 DAS as affected by different treatments

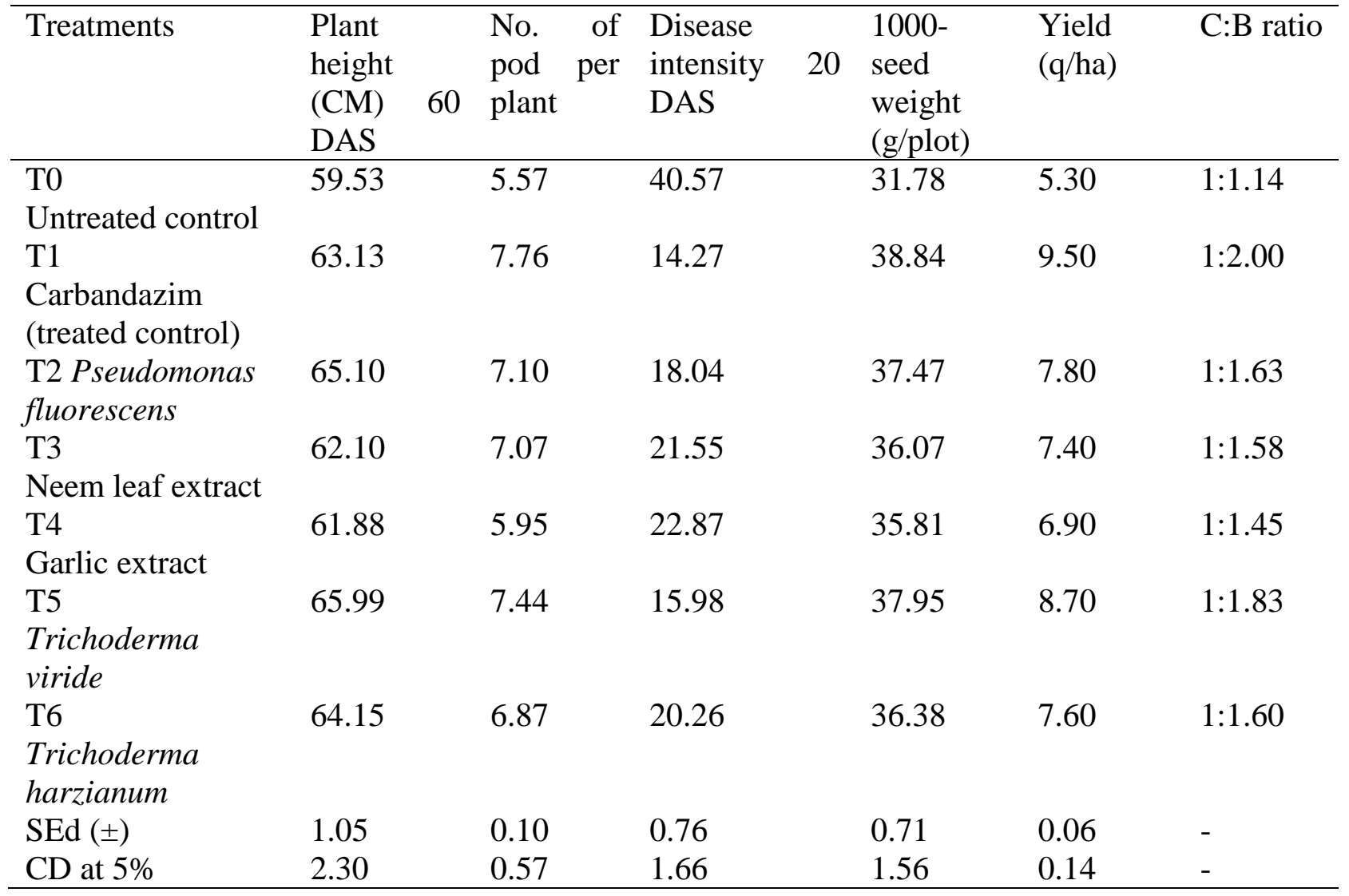

T2- Pseudomonas flourescens treatment was followed by $\mathrm{T}_{5}-$ Trichoderma viride @ 2.5\% (15.98\%), $\mathrm{T}_{6}-$ Trichoderma harzianum @ 2.5\%(20.26\%), T3- Neem leaf extract @ 20\% $(21.55 \%)$ and $\mathrm{T}_{4}-$ Garlic extract @ 10\% $(22.87 \%)$ as compared to T0 - control $(40.57 \%)$. Among the treatments lowest percent disease intensity was recorded in $\mathrm{T}_{1^{-}}$ Carbendazim 50 WP @ 0.1\% (14.27\%) and T2- Pseudomonas fluorescens @ 2\% (18.04\%). Similar findings were reported by Hossain and Hossain (2013) under field conditions. All the treatments tested in this study gave satisfactory result against cercospora leaf spot of green gram (Cercospora canescens). This may be due to activation of host defence mechanism and their ability to produce antimicrobial compounds, including 2, 4- diacetylphloroglucinol (DAPG), phenazines, hydrogen cyanide and surfactants. The results in 1000- seed weight ( $\mathrm{g}$ ) of field green gram is furnished in table 2 and depicted in figure 4.3. The data showed that all the treatment is significantly effective over control. Among all the bio- agent and botanical the maximum seed weight was recorded in $\mathrm{T}_{5}$ Trichoderma viride @2.5\% (37.96), followed by $\mathrm{T}_{2^{-}}$ Pseudomonas fluorescens @ 2\%, (37.47), $\mathrm{T}_{6}$ Trichoderma harzianum @2.5\% (36.83), $\mathrm{T}_{3}$ Neem leaf extract@10\% (36.11), T4 -Garlic extract @10\% (35.79), however $\mathrm{T}_{1}$ Carbendazim @0.1\% (38.78\%), is best fungicide comparison to all bio agent and botanical. The minimum seed weight recorded was $\mathrm{T}_{0}$-untreated control (31.6). The treatments the maximum grain yield $(\mathrm{q} / \mathrm{ha})$ was recorded in $\mathrm{T}_{5}$ - Trichoderma viride@ 
$2.5 \%(8.70 \mathrm{q} / \mathrm{ha})$ as compared to treated and untreated control $(9.50 \mathrm{q} / \mathrm{ha}$ and $5.30 \mathrm{q} / \mathrm{ha}$ and respectively). $\quad \mathrm{T}_{5}$-Trichoderma viride treatment was followed by T2- Pseudomonas fluorescens @ 2\% $\quad\left(7.80\right.$ q/ha), $\quad \mathrm{T}_{6^{-}}$ Trichoderma harzianum 7.60q/ha), $\mathrm{T}_{3}$ - Neem leaf extract@10\% (7.40 q/ha) and $\mathrm{T}_{4}$ - Garlic extract @10\% (5.95 q/ha) as compared to T0 - control (5.95 q/ha). Among the treatments miximum grain yield $(\mathrm{q} / \mathrm{ha})$ was recorded in $\mathrm{T}_{1}$ - Carbendazim 50 WP @ 0.1\% (7.76 q/ha) and $\mathrm{T}_{5}$ - Trichoderma viride @ 2.5\% (7.44 $\mathrm{q} / \mathrm{ha}$ ). When cost benefit ratio was calculated the best and most economical treatment was $\mathrm{T}_{5}$-Trichoderma viride @2.5\% (1:1.83), followed by $\mathrm{T}_{2}$-Pseudomonas fluorescens@ 2\% (1:1.68), $\mathrm{T}_{6-}$ Trichoderma harzianum@ $2.5 \%$ (1:1.60), $\mathrm{T}_{3-}$ - Neem leaf extract@10\% (1:1.58), $\mathrm{T}_{4^{-}}$Garlic extract @ 10\% (1:1.45) as compared to untreated $\mathrm{T}_{0}(1: 1.14)$, however $\mathrm{T}_{1}$ - Carbendazim @0.1\% (1:2.00), is best fungicide comparison to all bio agent and botanical.

\section{References}

Laxmipathi Gowda, C.L., Srinivasan S., Gaur P.M. and Saxena K.B. (2013) Enhancing the Productivity and Production of Pulses in India.

Abbaiah, p., Mahalakshmi and Alice, d. (1993). Induced Systemic Resistance by Plant Products and Nutrients in Green Gram Challenged with Powdery
Mildew Pathogen (Erysiphe polygoni DC.) International Journal of Plant Protection, Vol. 2 No. 2: 157-160.

Soria, J.A. and Quebral, F.C. (1973). Occurrence and development of powdery mildew on mungbean. Philippine Agricuture, 37:158-177.

AVRDC. (1984). AVRDC Progress report for 1982. Asian Vegetable Research and Development Center, Shanhua, Taiwan.p. 40-48.

Kapadiya, H.J. and Dhruj, I.U. (1999) Management of mung bean Cercospora leaf spot through fungicides. Indian Pytopath, 52(1):96-97.

Quebral, F. C. and Cowel, R. (1978). Powdery mildew and cercospora leaf spot of green gram in Philippines. First International Green gram Symposium, Philippines. pp. 147-148.

Venkata Rao, 1997, Studies on powdery mildew of green gram (Vigna radiata L.) caused by Erysiphe polygoni DC. M. Sc. (Agri.) Thesis, Univ. Agric. Sci., Dharwad (India).

Hossain, M.H. and Hossain, I. (2013) Screening of different plant extracts against leaf spot (Cercospora arachidicola and Cercosporidium personatum) of groundnut (Arachis hypogaea L.) Bangladesh j. Agril. Res. 38(3): 491-503.

\section{How to cite this article:}

Rajesh Kumar Yadav, S.S. Kakraliya, M.R. Bajiya and Sonali Abrol. 2017. Eco-Friendly Management of Powdery Mildew of Green Gram (Vigna radiata L.). Int.J.Curr.Microbiol.App.Sci. 6(7): 435-439. doi: https://doi.org/10.20546/ijcmas.2017.607.052 